\title{
Knowledge, attitudes, and practice of drivers towards traffic regulations in Bandar-Abbas, Iran
}

Abdolhamid Tajvar ${ }^{1}$, Mir Saeed Yekaninejad ${ }^{2}$, Teamur Aghamolaei ${ }^{3}$, Soudabeh Hamedi Shahraki ${ }^{4}$, Abdolhossein Madani $^{5}$, Leila Omidi ${ }^{6}$

${ }^{1}$ Lecturer of Occupational Health Engineering, Research Center for Social Determinants in Health Promotion, Hormozgan University of Medical Sciences, Bandar Abbas, Iran

${ }^{2}$ Assistant Professor of Biostatistics, Department of Epidemiology and Biostatistics, School of Public Health, Tehran University of Medical Sciences, Tehran, Iran

${ }^{3}$ Professor of Health Education, Research Center for Social Determinants in Health Promotion, Hormozgan University of Medical Sciences, Bandar Abbas, Iran

${ }^{4} \mathrm{Ph} . \mathrm{D}$. Candidate of Biostatistics, Department of Epidemiology and Biostatistics, School of Public Health, Tehran University of Medical Sciences, Tehran, Iran

${ }^{5}$ Associate Professor of Epidemiology, Research Center for Social Determinants in Health Promotion, Hormozgan University of Medical Sciences, Bandar Abbas, Iran

${ }^{6} \mathrm{Ph}$.D. Candidate of Occupational Health Engineering, Department of Occupational Health Engineering, School of Public Health, Tehran University of Medical Sciences, Tehran, Iran

Type of article: Original article

\begin{abstract}
Introduction: Traffic injuries are among the leading causes of death and disability in many countries. The knowledge, attitudes, and practice of drivers towards traffic regulations are key factors in decreasing traffic injuries and deaths. The objectives of this research were to study the knowledge, attitudes, and practice of taxi drivers towards traffic regulations in Bandar-Abbas, Iran, and to determine the relationships between demographic features and knowledge, attitudes, and practice of taxi drivers towards traffic regulations.

Methods: This cross-sectional study was done in 2014 in Bandar-Abbas, Iran (Hormozgan Province). To study the knowledge, attitudes, and practice of 241 intra-city taxi drivers towards traffic regulations, researchers developed questionnaires and a checklist. The chi-squared test was performed to determine the relationships between knowledge, attitude, and practice of drivers towards traffic regulations and demographic features.

Results: Among the 241 drivers, 50 of them (20.7\%) thought that the seat belt could cause discomfort while driving, and 107 (44.4\%) did not wear a seat belt while driving. The study determined that there was a significant difference between the knowledge and work experience of the drivers $(p=0.014)$. The 94 drivers $(43.5 \%)$ in the 31-40 year age group had positive attitudes towards traffic regulations (among 216 drivers expressed positive attitudes) and $92(44.4 \%)$ of the drivers in this age group had safe practices towards traffic regulations (among 207 drivers with safe practice).

Conclusion: Many of the taxi drivers in Bandar-Abbas had inadequate knowledge, less positive attitudes, and risky practices towards traffic regulations. Implementation of effective intervention programs may increase the taxi drivers' knowledge, attitudes, and practices towards traffic regulations.

Keywords: taxi drivers, knowledge, attitudes, practice, traffic regulations
\end{abstract}

\section{Introduction}

Traffic injuries are a leading cause of death and disability in many countries, and they are major public health problems (1-4). It is anticipated that the traffic accident rate could increase by $50 \%$ by the end of 2020 if appropriate

\section{Corresponding author:}

Leila Omidi, Department of Occupational Health Engineering, School of Public Health, Tehran University of Medical Sciences, Tehran, Iran. Tel: +98.2188951390, Fax: +98.2188954781, E-mail: omidil@razi.tums.ac.ir Received: August 01, 2015, Accepted: September 09, 2015, Published: December 2015

iThenticate screening: September 09, 2015, English editing: November 01, 2015, Quality control: November 10, 2015

(C) 2015 The Authors. This is an open access article under the terms of the Creative Commons Attribution-NonCommercialNoDerivs License, which permits use and distribution in any medium, provided the original work is properly cited, the use is non-commercial and no modifications or adaptations are made. 
actions are not taken to reduce global deaths due to traffic accidents (1). Some epidemiological studies have reported that the incidence rates of fatal traffic injuries are about 26.4, 17.4, and 19 per 100,000 people in the Eastern Mediterranean Region, in the European Region, and worldwide, respectively (5). In 2007, 27,567 deaths and 276,762 injuries as the result of traffic accidents were reported in Iran (1).

The knowledge, attitudes, and practice of drivers towards traffic regulations have been thought to be key factors in decreasing traffic injuries and deaths. Also, safe driving can have a significant impact. The issue of human factors, such as drivers' errors, seems to be a significant contributor to the rate of traffic injuries and deaths. The results of a study that was conducted in Saudi Arabia indicated that speed and non-compliance with rules were the main reasons for the high rate of injuries and deaths (6). A study of the knowledge, attitudes, and practices of 2200 drivers toward traffic regulations in Tehran and Zahedan indicated that the rate of road traffic crashes can be decreased by increasing the levels of knowledge of drivers and by changing their attitudes and practices. A significant association was found between safer attitudes and decreases in the rate of traffic crashes $(O R=0.76, p=0.007)(7)$.

Many observers have mentioned the importance of determining the relationships between personality and demographic variables (such as age, gender, and education levels) and drivers' behaviors. In low-income countries, driving attitudes and behaviors may be influenced by age and gender. Drivers' attitudes towards traffic regulations could be associated with driving violations (8). Intention to commit driving violations, high-speed driving, and poor decision making are important risk factors for traffic accidents (9).

Some previous studies have reported a weak association between knowledge, attitudes toward driving, and driving behavior (10). Various surveys, such as the one conducted by Yunesian and Moradi, have shown that 67.7, 56.4, and $47.7 \%$ of drivers had adequate knowledge, positive attitudes, and safe practice towards traffic regulations, respectively. Their findings suggested that the type of automobile, education levels, occupation, and marital status had significant effects on drivers' practices. Drivers' levels of knowledge were significantly related to their age. Young drivers are most likely to be involved in traffic accidents. The researchers conclude that drivers in Teheran City had risky practices towards traffic regulations (11). Although, there has been considerable debate concerning whether attitudes predict behavior, several research studies have indicated that attitudes do, in fact, affect behavior. Changing people's attitudes towards traffic regulations has been considered to be a key element in the prevention of traffic crashes (12). Developing a culture of safety is the most effective strategy to prevent breaking the rules (13). Some studies have shown that the use of seat belts by drivers reduces the risk of fatal injuries and reduces the severity of the effects of accidents on the occupants of vehicles. The most common causes of car accidents in Malaysia were high-speed driving, dangerous driving, and the careless overtaking of other vehicles, i.e., with these causes contributing to $32.8,28.2$, and $15.1 \%$ of all accidents, respectively. The major cause of traffic accidents was drivers' behaviors (76.1\%) (14). Traffic accidents are the main causes of disability-adjusted life years (DALYs) in Iran. More than 30,000 deaths due to traffic accidents are reported in Iran each year, with an associated fatal incidence rate of 44 per 100,000) (15). The estimated cost of traffic injuries in Iran in 2012 was 180,000 billion Iranian rails (US\$ 6,000,000,000), which amounted to 6.64\% of Iran's gross national income in 2013 (16). However, to date, there has been little discussion about the rate of traffic injuries and the related costs in BandarAbbas. The objectives of this research were to study the knowledge, attitudes, and practices of taxi drivers towards traffic regulations in Bandar-Abbas, Iran, and to determine the relationships between demographic features and the knowledge, attitudes, and practices of drivers towards traffic regulations.

\section{Material and Methods}

\subsection{Research design and setting}

This cross-sectional study was conducted in 2014 in Bandar-Abbas County, Hormozgan Province, Iran. According to some cross-sectional studies performed in Bandar-Abbas on automobile drivers $(17,18)$, there is a need for more research on drivers' behaviors in this city to reduce the severity of accidents and the fatality rates.

\subsection{Sampling}

We used the following formula to determine the sample size:

$\mathrm{n}=\mathrm{Z}_{1-\alpha / 2} \mathrm{p}(1-\mathrm{p}) / \mathrm{d}^{2}$, where $\mathrm{n}$ is the required sample size, $\mathrm{Z}_{1-\alpha / 2}$ is the value for a level of confidence (1.96), $\mathrm{p}$ is the expected proportion (0.5), and $d$ is the precision (0.04). Based on this formula, a sample size of 306 male taxi drivers was determined. Sixty-five drivers refused to participate in the study. Twenty-two drivers were unwilling to complete the questionnaire. Another 43 drivers worked for exclusive taxi services and said they did not have time to 
participate in the research. Thus, a total of 241 drivers (response rate $78.7 \%$ ) who operated within the city of Bandar-Abbas participated in this study, and the data obtained from these drivers were used for the analyses.

\subsection{Measurement tool}

To study the knowledge, attitudes, and practices of intra-city drivers towards traffic regulations in Bandar-Abbas, the two authors designed questionnaires to assess their knowledge and attitudes and a checklist for assessing the drivers' practices were used. The knowledge questionnaire included 15 questions extracted from parts of Iran's driver's license test. The internal consistency of the knowledge questionnaire was assessed by Cronbach's alpha ( $\alpha=$ 0.82 ). The attitude questionnaire included seven questions that were designed to assess drivers' attitudes in relation to various traffic regulations. It was prepared under the supervision of experienced traffic police officers, and it included various items, such as using seat belts, exceeding the speed limit in low-volume traffic on intercity roads, driving in restricted areas in an emergency situation, keeping a safe distance behind the car in front, crossing the center line of a road in low-volume traffic, coming to a complete stop before entering a main street from a side street, and eating and drinking while driving. The internal consistency of the attitude questionnaire was assessed by Cronbach's alpha $(\alpha=0.75)$. The checklist was used to assess drivers' practices. This checklist included 35 questions concerning drivers' behaviors, such as risky overtaking maneuvers, exceeding the speed limit over speed bumps, turning in prohibited areas, sudden braking, and running a red light.

\subsection{Statistical analyses}

SPSS version 18.0 (SPSS, Inc., Chicago, IL, USA) was used to analyze the data. The mean and standard deviation (SD) were used to report the numerical data, while frequency and percentage were used to report qualitative variables. The chi-squared test was performed to determine the relationships between the knowledge, attitudes, and practices of taxi drivers towards traffic regulations and demographic features.

\section{Results}

Tables 1 and 2 illustrate the questions about attitudes and practices and the percentage and frequency of drivers' responses to attitude and practice items towards traffic regulations, respectively. The demographic characteristics of the participants are presented in Table 3. The highest number of participants (55 drivers) was in the 31-35 age group. Two hundred thirty-eight of them (98.8\%) were married. Among all of the drivers, 113 obtained their driver's license between 1992 and 2002. Among the 241 drivers, 97 (40.2\%) had completed the middle school educational level, 32.4\% of them had work experience of 6-10 years. As shown in Tables 1 and 2, 120 drivers (49.8\%) totally agreed with the statement, "Eating and drinking while driving is dangerous." and 124 of them (51.5\%) believed that it is necessary to keep a safe distance from a car in front. Fifty drivers $(20.7 \%)$ thought that seat belts may cause discomfort while driving. One hundred and seven taxi drivers did not wear a seat belt while driving and 190 of them (78.8\%) exchanged taxi fares while driving.

Table 1. Percentage and frequency $(n)$ of responses to attitude items

\begin{tabular}{|l|l|l|l|l|l|l|l|l|l|l|l|}
\hline & \multicolumn{2}{l|}{$\begin{array}{l}\text { Totally } \\
\text { agree }\end{array}$} & \multicolumn{2}{l|}{ Agree } & \multicolumn{2}{l|}{ Neutral } & \multicolumn{2}{l|}{ Disagree } & \multicolumn{2}{l|}{$\begin{array}{l}\text { Totally } \\
\text { disagree }\end{array}$} \\
\hline Attitude sentences & $\mathrm{n}$ & $\%$ & $\mathrm{n}$ & $\%$ & $\mathrm{n}$ & $\%$ & $\mathrm{n}$ & $\%$ & $\mathrm{n}$ & $\%$ \\
\hline $\begin{array}{l}\text { The seat belt may cause discomfort while } \\
\text { driving. }\end{array}$ & 50 & 20.7 & 39 & 16.3 & 6 & 2.5 & 97 & 40.6 & 47 & 19.7 \\
\hline $\begin{array}{l}\text { In very light traffic in the intercity roads, } \\
\text { the drivers can exceed the speed limit. }\end{array}$ & 11 & 4.6 & 30 & 12.4 & 17 & 7 & 118 & 49 & 65 & 27 \\
\hline $\begin{array}{l}\text { In an emergency, drivers can drive in } \\
\text { prohibited areas. }\end{array}$ & 2 & 0.8 & 43 & 17.8 & 14 & 5.8 & 124 & 51.5 & 58 & 24.1 \\
\hline $\begin{array}{l}\text { It is necessary to keep a safe distance from } \\
\text { a car in front. }\end{array}$ & 124 & 51.4 & 87 & 36.1 & 7 & 2.9 & 17 & 7.1 & 6 & 2.5 \\
\hline $\begin{array}{l}\text { In very light traffic, the drivers can cross } \\
\text { the center line of a road. }\end{array}$ & 20 & 8.2 & 62 & 25.7 & 17 & 7.1 & 118 & 49 & 24 & 10 \\
\hline $\begin{array}{l}\text { It is necessary to stop driving before } \\
\text { entering a main street from a side street. }\end{array}$ & 110 & 45.6 & 89 & 36.9 & 8 & 3.3 & 27 & 11.2 & 7 & 2.9 \\
\hline $\begin{array}{l}\text { Eating and drinking while driving are } \\
\text { dangerous. }\end{array}$ & 120 & 49.8 & 84 & 34.9 & 8 & 3.3 & 17 & 7.1 & 12 & 5 \\
\hline
\end{tabular}


Table 2. Percentage and frequency (n) of responses to practice items

\begin{tabular}{|c|c|c|c|c|}
\hline \multirow[t]{2}{*}{ Practice items } & \multicolumn{2}{|l|}{ Yes } & \multicolumn{2}{|l|}{ No } \\
\hline & $\mathrm{n}$ & $\%$ & $\mathrm{n}$ & $\%$ \\
\hline Not using a seat belt & 107 & 44.4 & 134 & 55.6 \\
\hline Using a phone while driving & 103 & 42.7 & 138 & 57.3 \\
\hline Speaking with passengers while driving & 173 & 71.8 & 68 & 28.2 \\
\hline Exchanging taxi fare while driving & 190 & 78.8 & 51 & 21.2 \\
\hline Smoking while driving & 10 & 4.1 & 231 & 95.9 \\
\hline Using a defective kilometer counter & 24 & 10 & 216 & 89.6 \\
\hline Not gripping the steering wheel with both hands & 185 & 76.8 & 56 & 23.2 \\
\hline Failure to hold the steering wheel while driving & 98 & 40.7 & 143 & 59.3 \\
\hline Eating and drinking while driving & 26 & 10.8 & 215 & 89.2 \\
\hline Driving over the speed limit & 112 & 46.5 & 129 & 53.5 \\
\hline Driving while fatigued and drowsy & 53 & 22 & 188 & 78 \\
\hline Become angry while driving & 43 & 17.8 & 198 & 82.2 \\
\hline Opening the car door without paying sufficient attention & 98 & 40.7 & 143 & 59.3 \\
\hline Failure to use the handbrake while stopping & 180 & 47.7 & 61 & 25.3 \\
\hline Poor position of driver and passengers & 69 & 28.6 & 172 & 71.4 \\
\hline Running a red light & 38 & 15.8 & 203 & 84.2 \\
\hline Using the high beam when approaching an oncoming vehicle at night & 6 & 10.9 & 49 & 89.1 \\
\hline Using the horn in a restricted area & 18 & 7.5 & 223 & 92.5 \\
\hline Failure to wear glasses by drivers with poor eyesight & 22 & 15.3 & 122 & 84.7 \\
\hline Failure to maintain a safe side distance to bicycles and motorcycles & 96 & 39.8 & 145 & 60.2 \\
\hline Boarding passengers exceeding the vehicle's capacity & 35 & 14.5 & 206 & 85.5 \\
\hline Sudden braking & 159 & 66 & 82 & 34 \\
\hline Not looking into the side mirrors while overtaking another vehicle & 83 & 34.4 & 158 & 65.6 \\
\hline Failure to stay at least two seconds behind a car in front & 144 & 61.3 & 91 & 38.7 \\
\hline Zigzag and spiral maneuvers & 69 & 28.6 & 172 & 71.4 \\
\hline Not driving between the lines & 101 & 41.9 & 140 & 58.1 \\
\hline Not using the signal lights while turning & 87 & 36.1 & 154 & 63.9 \\
\hline Driving in reverse & 68 & 28.2 & 173 & 71.8 \\
\hline Crossing the sidewalk & 33 & 13.7 & 208 & 86.3 \\
\hline Driving too fast over speed bumps & 100 & 41.5 & 141 & 58.5 \\
\hline Crossing prohibited areas & 47 & 19.5 & 194 & 80.5 \\
\hline Turning in prohibited areas & 10 & 4.1 & 231 & 95.9 \\
\hline Risky overtaking maneuvers & 107 & 44.4 & 134 & 55.6 \\
\hline Fail to follow the priority rules & 66 & 27.4 & 175 & 72.6 \\
\hline Stopping in prohibited areas & 40 & 16.6 & 201 & 83.4 \\
\hline
\end{tabular}

The relationships between demographic features and drivers' knowledge are presented in Table 4. There were no significant relationships between age, educational levels, and the year the drivers obtained their driver's licenses and drivers' knowledge $(\mathrm{p}>0.05)$. The chi-squared test showed a significant difference between knowledge and the work experience of drivers $(\mathrm{p}=0.014)$. Approximately $30.2 \%$ of the drivers (among 169 drivers) who had 6-10 years of work experience had adequate knowledge about traffic regulations. The results, as shown in Table 5, indicated that there were no significant relationships between demographic features and the attitudes of drivers towards traffic regulations ( $p>0.05$ ). Approximately $43.5 \%$ of the drivers in the $31-40$ year age group had positive attitudes towards traffic regulations (among 216 drivers expressed positive attitudes), while $46.8 \%$ of the drivers in this group who had diplomas and higher levels of education had positive attitudes. Among the drivers who obtained their driver's licenses between 1992 and 2002, 45.4\% reported positive attitudes towards traffic regulations. The data in Table 6 indicate that there were no significant differences between the drivers' practices and their demographic features $(\mathrm{p}>0.05)$. Ninety two drivers $(44.4 \%)$ in the $31-40$ age group had safe practices towards traffic regulations (among 207 drivers with safe practice). In the group that had 6 to 10 years of work experience, 71 drivers (34.3\%) had safe practices towards traffic regulations. 
Table 3. Demographic characteristics of the drivers

\begin{tabular}{|c|c|c|c|}
\hline Variables & Category & $\mathrm{n}$ & $\%$ \\
\hline \multirow[t]{5}{*}{ Age (year) } & $20-30$ & 37 & 15.4 \\
\hline & $31-40$ & 104 & 43.1 \\
\hline & $41-50$ & 64 & 26.5 \\
\hline & $51-60$ & 30 & 12.4 \\
\hline & $>60$ & 6 & 2.5 \\
\hline \multirow[t]{2}{*}{ Marital status } & Single & 3 & 1.2 \\
\hline & Married & 238 & 98.8 \\
\hline \multirow{4}{*}{$\begin{array}{l}\text { Year driver's license was } \\
\text { obtained }\end{array}$} & $1972-1982$ & 14 & 5.8 \\
\hline & 1982-1992 & 38 & 15.8 \\
\hline & $1992-2002$ & 113 & 46.9 \\
\hline & $2002-2011$ & 76 & 31.5 \\
\hline \multirow[t]{6}{*}{ Educational levels } & Illiterate & 14 & 5.8 \\
\hline & Elementary & 17 & 7.1 \\
\hline & Middle school & 97 & 40.2 \\
\hline & Diploma & 96 & 39.8 \\
\hline & Higher diploma & 15 & 6.2 \\
\hline & Bachelor & 2 & 0.8 \\
\hline \multirow[t]{7}{*}{ Work experience (year) } & $1-5$ & 46 & 19.1 \\
\hline & $6-10$ & 78 & 32.4 \\
\hline & $11-15$ & 66 & 27.4 \\
\hline & $16-20$ & 30 & 12.4 \\
\hline & $21-25$ & 11 & 4.6 \\
\hline & $26-30$ & 7 & 2.9 \\
\hline & $31-35$ & 3 & 1.2 \\
\hline
\end{tabular}

Table 4. Relationships between demographic features and drivers' knowledge

\begin{tabular}{|c|c|c|c|c|c|c|c|c|}
\hline \multicolumn{2}{|l|}{ Variables } & \multicolumn{2}{|c|}{ Adequate knowledge } & \multicolumn{2}{|c|}{ Inadequate knowledge } & \multicolumn{3}{|c|}{ Results of the analysis } \\
\hline Age (year) & $<30$ & $\begin{array}{l}\mathrm{n} \\
29\end{array}$ & $\begin{array}{l}\% \\
17.2\end{array}$ & $\begin{array}{l}\mathrm{n} \\
8\end{array}$ & $\begin{array}{l}\% \\
11.1\end{array}$ & $\frac{\chi^{2}}{3.388}$ & $\frac{\mathrm{df}}{3}$ & $\begin{array}{l}\mathrm{p} \\
0.336\end{array}$ \\
\hline & $31-40$ & 73 & 432 & 31 & 431 & & & \\
\hline & $41-50$ & 40 & 23.7 & 24 & 333 & & & \\
\hline & $>50$ & 27 & 16 & 9 & 12.5 & & & \\
\hline \multicolumn{2}{|l|}{ Total } & 169 & 100 & 72 & 100 & & & \\
\hline \multirow[t]{3}{*}{$\begin{array}{l}\text { Educational } \\
\text { levels }\end{array}$} & $\begin{array}{l}\text { Illiterate and } \\
\text { elementary }\end{array}$ & 18 & 10.7 & 13 & 18.1 & \multirow[t]{4}{*}{2.521} & \multirow[t]{4}{*}{2} & \multirow[t]{4}{*}{0.284} \\
\hline & Middle school & 69 & 40.8 & 28 & 38.9 & & & \\
\hline & $\begin{array}{l}\text { Diploma and } \\
\text { higher }\end{array}$ & 82 & 48.5 & 31 & 43.1 & & & \\
\hline \multicolumn{2}{|l|}{ Total } & 207 & 100 & 34 & 100 & & & \\
\hline \multirow{4}{*}{$\begin{array}{l}\text { Year } \\
\text { driver's } \\
\text { license was } \\
\text { obtained }\end{array}$} & $1972-1982$ & 12 & 7.1 & 2 & 2.8 & \multirow[t]{5}{*}{6.250} & \multirow[t]{5}{*}{3} & \multirow[t]{5}{*}{0.100} \\
\hline & $1982-1992$ & 31 & 18.3 & 7 & 9.7 & & & \\
\hline & $1992-2002$ & 72 & 42.6 & 41 & 56.9 & & & \\
\hline & $2002-2011$ & 54 & 32 & 22 & 30.6 & & & \\
\hline \multicolumn{2}{|l|}{ Total } & 169 & 100 & 72 & 100 & & & \\
\hline \multirow{5}{*}{$\begin{array}{l}\text { Work } \\
\text { experience } \\
\text { (year) }\end{array}$} & $1-5$ & 39 & 23.1 & 7 & 14.7 & \multirow[t]{6}{*}{12.500} & \multirow[t]{6}{*}{4} & \multirow[t]{6}{*}{0.014} \\
\hline & $6-10$ & 51 & 30.2 & 27 & 20.6 & & & \\
\hline & $11-15$ & 42 & 24.9 & 24 & 26.5 & & & \\
\hline & $16-20$ & 18 & 10.7 & 12 & 20.6 & & & \\
\hline & $>20$ & 19 & 11.2 & 62 & 17.6 & & & \\
\hline \multicolumn{2}{|l|}{ Total } & 169 & 100 & 72 & 100 & & & \\
\hline
\end{tabular}


Table 5. Relationships between demographic features and drivers' attitudes

\begin{tabular}{|c|c|c|c|c|c|c|c|c|}
\hline \multirow{2}{*}{\multicolumn{2}{|c|}{ Variables }} & \multicolumn{2}{|c|}{ Positive attitude } & \multicolumn{2}{|c|}{ Negative attitude } & \multicolumn{3}{|c|}{ Results of the analysis } \\
\hline & & $\mathrm{n}$ & $\%$ & $\mathrm{n}$ & $\%$ & $\chi^{2}$ & $\mathrm{df}$ & $\mathrm{p}$ \\
\hline \multirow[t]{4}{*}{ Age (year) } & $<30$ & 35 & 16.2 & 2 & 8 & \multirow[t]{5}{*}{1.836} & \multirow[t]{5}{*}{3} & \multirow[t]{5}{*}{0.607} \\
\hline & $31-40$ & 94 & 43.5 & 10 & 40 & & & \\
\hline & $41-50$ & 56 & 25.9 & 8 & 32 & & & \\
\hline & $>50$ & 31 & 14.4 & 5 & 20 & & & \\
\hline \multicolumn{2}{|l|}{ Total } & 216 & 100 & 25 & 100 & & & \\
\hline \multirow[t]{3}{*}{$\begin{array}{l}\text { Educational } \\
\text { levels }\end{array}$} & $\begin{array}{l}\text { Illiterate and } \\
\text { elementary }\end{array}$ & 29 & 13.4 & 2 & 8 & \multirow[t]{4}{*}{0.618} & \multirow[t]{4}{*}{2} & \multirow[t]{4}{*}{0.734} \\
\hline & Middle school & 86 & 39.8 & 11 & 44 & & & \\
\hline & $\begin{array}{l}\text { Diploma and } \\
\text { higher }\end{array}$ & 101 & 46.8 & 12 & 48 & & & \\
\hline \multicolumn{2}{|l|}{ Total } & 216 & 100 & 25 & 100 & & & \\
\hline \multirow{4}{*}{$\begin{array}{l}\text { Year } \\
\text { driver's } \\
\text { license was } \\
\text { obtained }\end{array}$} & $1972-1982$ & 14 & 6.5 & 0 & 0 & \multirow[t]{5}{*}{4.137} & \multirow[t]{5}{*}{3} & \multirow[t]{5}{*}{0.247} \\
\hline & $1982-1992$ & 33 & 15.3 & 5 & 20 & & & \\
\hline & $1992-2002$ & 98 & 45.4 & 15 & 60 & & & \\
\hline & $2002-2011$ & 71 & 32.9 & 5 & 20 & & & \\
\hline \multicolumn{2}{|l|}{ Total } & 216 & 100 & 25 & 100 & & & \\
\hline \multirow{5}{*}{$\begin{array}{l}\text { Work } \\
\text { experience } \\
\text { (year) }\end{array}$} & $1-5$ & 44 & 20.4 & 2 & 8 & \multirow[t]{6}{*}{2.852} & \multirow[t]{6}{*}{4} & \multirow[t]{6}{*}{0.583} \\
\hline & $6-10$ & 70 & 32.4 & 8 & 32 & & & \\
\hline & $11-15$ & 57 & 26.4 & 9 & 36 & & & \\
\hline & $16-20$ & 26 & 12 & 4 & 16 & & & \\
\hline & $>20$ & 19 & 8.8 & 2 & 8 & & & \\
\hline \multicolumn{2}{|l|}{ Total } & 216 & 100 & 25 & 100 & & & \\
\hline
\end{tabular}

Table 6. Relationships between demographic features and drivers' practices

\begin{tabular}{|c|c|c|c|c|c|c|c|c|}
\hline \multicolumn{2}{|l|}{ Variables } & \multicolumn{2}{|c|}{ Safe practice } & \multicolumn{2}{|c|}{ Unsafe practice } & \multicolumn{3}{|c|}{ Results of the analysis } \\
\hline & & $\mathrm{n}$ & $\%$ & $\mathrm{n}$ & $\%$ & $\chi^{2}$ & $\mathrm{df}$ & $\mathrm{p}$ \\
\hline \multirow[t]{4}{*}{ Age (year) } & $<30$ & 34 & 16.4 & 3 & 8.8 & \multirow[t]{5}{*}{5.312} & \multirow[t]{5}{*}{3} & \multirow[t]{5}{*}{0.150} \\
\hline & $31-40$ & 92 & 44.4 & 12 & 35.3 & & & \\
\hline & $41-50$ & 54 & 26.1 & 10 & 29.4 & & & \\
\hline & $>50$ & 27 & 13 & 9 & 26.5 & & & \\
\hline \multicolumn{2}{|l|}{ Total } & 207 & 100 & 34 & 100 & & & \\
\hline \multirow[t]{3}{*}{$\begin{array}{l}\text { Educational } \\
\text { levels }\end{array}$} & $\begin{array}{l}\text { Illiterate and } \\
\text { elementary }\end{array}$ & 25 & 12.1 & 6 & 17.6 & \multirow[t]{4}{*}{2.169} & \multirow[t]{4}{*}{2} & \multirow[t]{4}{*}{0.338} \\
\hline & Middle school & 87 & 42 & 10 & 29.4 & & & \\
\hline & $\begin{array}{l}\text { Diploma and } \\
\text { higher }\end{array}$ & 95 & 45.9 & 18 & 53 & & & \\
\hline \multicolumn{2}{|l|}{ Total } & 207 & 100 & 34 & 100 & & & \\
\hline \multirow{4}{*}{$\begin{array}{l}\text { Year } \\
\text { driver's } \\
\text { license was } \\
\text { obtained }\end{array}$} & $1972-1982$ & 11 & 5.3 & 3 & 8.8 & \multirow[t]{5}{*}{2.007} & \multirow[t]{5}{*}{3} & \multirow[t]{5}{*}{0.571} \\
\hline & $1982-1992$ & 31 & 15 & 7 & 20.6 & & & \\
\hline & $1992-2002$ & 97 & 46.9 & 16 & 47.1 & & & \\
\hline & $2002-2011$ & 68 & 32.9 & 8 & 23.5 & & & \\
\hline \multicolumn{2}{|l|}{ Total } & 207 & 100 & 34 & 100 & & & \\
\hline \multirow{5}{*}{$\begin{array}{l}\text { Work } \\
\text { experience } \\
\text { (year) }\end{array}$} & $1-5$ & 41 & 19.8 & 5 & 14.7 & \multirow[t]{6}{*}{7.839} & \multirow[t]{6}{*}{4} & \multirow[t]{6}{*}{0.098} \\
\hline & $6-10$ & 71 & 34.3 & 7 & 20.6 & & & \\
\hline & $11-15$ & 57 & 27.5 & 9 & 26.5 & & & \\
\hline & $16-20$ & 23 & 11.1 & 7 & 20.6 & & & \\
\hline & $>20$ & 15 & 7.2 & 6 & 17.6 & & & \\
\hline \multicolumn{2}{|l|}{ Total } & 207 & 100 & 34 & 100 & & & \\
\hline
\end{tabular}




\section{Discussion}

The objectives of the current study were to study the knowledge, attitudes, and practices of taxi drivers towards traffic regulations in Bandar-Abbas, Iran, and to determine the relationships between demographic features and knowledge, attitudes, and practices of drivers towards traffic regulations. The results showed that many taxi drivers had positive attitudes towards traffic regulations. Ninety-seven drivers (40.6\%) disagreed that the use of a seat belt caused discomfort. Approximately $44.4 \%$ of drivers did not wear a seat belt while driving. The importance of the wearing a seat belt has been mentioned in many previous studies $(6,7)$. The findings of many studies have shown that wearing a seat belt may decrease the risk and severity of injuries. Mehri et al. demonstrated that the rate of using seat belts among Iranian drivers was very low. Although most of the drivers in their study (88\%) were aware of the effectiveness and benefits of wearing a seat belt in decreasing the severity of injuries in traffic crashes, only $63 \%$ of them actually wore a seat belt while driving (19). Approximately $15.8 \%$ of the drivers admitting to running red lights, and $44.4 \%$ of them performed risky overtaking maneuvers, both of which increase the risks of traffic accidents (20). Most of the drivers believed that engaging in distracting activities, such as eating and drinking is dangerous while driving (49.8\% totally agree and 34.9\% agree). However, $10.8 \%$ of them engaged in these distracting activities. The results of other studies have indicated that distracting activities may decrease the driver's performance (21). Among the 241 drivers in the current study, 103 of the drivers (42.7\%) used a mobile phone while driving. Among 287 Victorian drivers (Australian state of Victoria), 60\% of them used mobile phone while driving, and one-third of them used their phone in the hand-held mode (22). Also, the results of some studies indicated that talking on a cell phone may increase the risks of traffic accidents (23).

The results obtained from the assessment of relationships between demographic features and drivers' knowledge indicated that drivers in the 31-40 age group had adequate knowledge of traffic regulations. The chi-squared test showed a significant difference between drivers' knowledge and the work experience of taxi drivers. A greater knowledge of traffic regulations was reported in drivers in the group that had 6-10 years of work experience. Eightytwo drivers $(48.5 \%)$ with the educational levels of diploma and higher had greater knowledge of traffic regulations than the other drivers. The study of drivers' knowledge, attitudes and practices in Tehran illustrated a significant relationship between education levels and drivers' knowledge $(p=0.02)$. No significant differences were found between other demographic features and drivers' knowledge. In other words, the levels of drivers' knowledge increased as their educational levels increased (11). Although no significant differences were found between drivers' knowledge and their educational levels in the current study, a greater knowledge towards traffic regulations was reported in $48.5 \%$ of drivers with higher educational levels.

The chi-squared test did not show any significant differences between the attitudes of drivers towards traffic regulations and demographic features. The findings of Yunesian and Moradi indicated that there were significant differences between the attitudes of drivers and two demographic variables of drivers, i.e., age $(p=0.02)$ and marital status $(p=0.002)$. No significant differences were found between other demographic features and drivers' attitudes. The more positive attitudes were observed in older drivers (11). The most positive attitudes towards traffic regulations in this study (43.5\%) were reported in taxi drivers in the 31-40 age group (among 216 drivers expressed positive attitudes).

There were no significant differences between the demographic features of drivers and their practices. The safer practices (44.4\%) were reported in drivers in the 31-40 year age group (among 207 drivers with safe practice), drivers with the educational levels of diploma and higher (45.9\%), and drivers in the group that had 6-10 years of work experience. These findings were consistent with other research in which it was found that drivers with higher educational levels may have safer practices than those with lower educational levels (11). Many of the taxi drivers in Bandar-Abbas had inadequate knowledge, less positive attitudes, and risky practices towards traffic regulations. The increase in knowledge, attitudes, and practices of taxi drivers towards traffic regulations may decrease the rate of traffic injuries and deaths. Implementation of effective intervention programs may increase the taxi drivers' knowledge, attitudes, and practices towards traffic regulations. A limitation of this study was that the relationships between the knowledge, attitudes, and practices of taxi drivers towards traffic regulations and traffic crashes were not examined. Further experimental investigations are needed to estimate the relationships between these factors.

\section{Conclusions}

Many taxi drivers in Bandar-Abbas had inadequate knowledge, less positive attitudes, and risky practices towards traffic regulations. Drivers' knowledge was significantly related to their work experience. Implementation of 
effective intervention programs may increase the taxi drivers' knowledge, attitudes, and practices towards traffic regulations.

\section{Acknowledgments:}

This research was supported by Hormozgan University of Medical Sciences (project No. 9290). The authors thank the staff members of the University who provided technical and financial assistance. We also sincerely appreciated the cooperation of the drivers who participated in the study.

\section{Conflict of Interest:}

There is no conflict of interest to be declared.

\section{Authors' contributions:}

All authors contributed to this project and article equally. All authors read and approved the final manuscript.

\section{References}

1) Bahadorimonfared A, Soori H, Mehrabi Y, Delpisheh A, Esmaili A, et al. Trends of fatal road traffic injuries in Iran (2004-2011). PLoS ONE. 2013; 8 (5): e65198. doi:10.1371/journal.pone.0065198, PMID: 23724132, PMCID: PMC3665536.

2) Krug EG, Sharma GK, Lozano R. The global burden of injuries. Am J Public Health. 2000; 90 (4): 523. PMID: 10754963, PMCID: PMC1446200.

3) Nantulya VM, Reich MR. The neglected epidemic: road traffic injuries in developing countries. BMJ. 2002; 324 (7346): 1139. PMID: 12003888, PMCID: PMC1123095.

4) Hatamabadi HR, Vafaee R, Haddadi M, Abdalvand A, Soori H. Necessity of an integrated road traffic injuries surveillance system: a community-based study. Traffic Inj Prev. 2011; 12(4): 358-62. doi: 10.1080/15389588.2011.566656, PMID: 21823944.

5) Saadat S, Soori H. Epidemiology of traffic injuries and motor vehicles utilization in the Capital of Iran: A population based study. BMC public health. 2011; 11 (1): 488. doi: 10.1186/1471-2458-11-488, PMID: 21693056 , PMCID: PMC3141457.

6) Al-Khaldi YM. Attitude and practice towards road traffic regulations among students of health sciences college in Aseer region. J Family Community Med. 2006; 13 (3): 109-13. PMID: 23012129, PMCID: PMC3410057.

7) Mirzaei R, Hafezi-Nejad N, Sabagh MS, Moghaddam AA, Eslami V, Rakhshani F, et al. Dominant role of drivers' attitude in prevention of road traffic crashes: A study on knowledge, attitude, and practice of drivers in Iran. Accid Anal Prev. 2014; 66: 36-42. doi:10.1016/j.aap.2014.01.013, PMID: 24508588.

8) Akaateba MA, Amoh-Gyimah R. Driver attitude towards traffic safety violations and risk taking behaviour in Kumasi: the gender and age dimension. International Journal for Traffic and Transport Engineering. 2013; 3 (4): 479-94. doi: 10.7708/ijtte.2013.3(4).10.

9) Parker D, West R, Stradling S, Manstead AS. Behavioural characteristics and involvement in different types of traffic accident. Accid Anal Prev. 1995; 27 (4): 571-81. doi:10.1016/0001-4575(95)00005-K, PMID: 7546068.

10) Gebers MA. Knowledge and attitude change and the relationship to driving performance among drivers attending California traffic violator school. RSS-95-147: California Department of Motor Vehicles Sacramento; 1995.

11) Yunesian M, Moradi A. Knowledge, attitude and practice of drivers regarding traffic regulations in Tehran. J Sch Publ Health Inst Publ Health Res. 2005; 3 (3): 57-66. Persian.

12) Martinussen LM, Prato CG, Møller M. Facilitating improved road safety based on increased knowledge about driving behaviour and profiling sub-groups of drivers: Technical University of DenmarkDanmarks Tekniske Universitet, Department of TransportInstitut for Transport, Traffic Safety Trafiksikkerhed; 2013.

13) Jafari MJ, Gharari M, Ghafari M, Omidi L, Kalantari S, Fardi GRA. The influence of safety training on safety climate factors in a construction site. Int J Occup Hyg. 2014; 6 (2): 81-7.

14) Redhwan A, Karim A. Knowledge, attitude and practice towards road traffic regulations among university students, Malaysia. The International Medical Journal of Malaysia. 2010; 9 (2): 29-34.

15) Shahraz S, Bartels D, Puthenpurakal JA, Motlagh ME. Adverse health outcomes of road traffic injuries in Iran after rapid motorization. Arch Iran Med. 2009; 12 (3): 284-94. PMID: 19400607. 
16) Ainy E, Soori H, Ganjali M, Le H, Baghfalaki T. Estimating cost of road traffic injuries in Iran using willingness to pay (WTP) method. PLoS ONE. 2014; 9 (12): e112721. doi:10.1371/journal.pone.0112721, PMCID: PMC4249801.

17) Tavafian SS, Aghamolaei T, Gregory D, Madani A. Prediction of seat belt use among Iranian automobile drivers: application of the theory of planned behavior and the health belief model. Traffic Inj Prev. 2011; 12 (1): 48-53. doi: 10.1080/15389588.2010.532523, PMID: 21259173.

18) Tavafian SS, Aghamolaei T, Madani A. Predictors of speeding behavior among a sample of Iranian commercial automobile drivers: an application of the theory of planned behavior. Traffic Inj Prev. $2011 ; 12$ (3): 274-8. doi: 10.1080/15389588.2011.553976, PMID: 21660894.

19) Ali M, Haidar N, Ali MM, Maryam A. Determinants of seat belt use among drivers in Sabzevar, Iran: a comparison of theory of planned behavior and health belief model. Traffic Inj Prev. 2011; 12 (1): 104-9. doi: 10.1080/15389588.2010.535227. PMID: 21259180.

20) Clarke DD, Ward PJ, Jones J. Overtaking road-accidents: Differences in manoeuvre as a function of driver age. Accid Anal Prev. 1998; 30 (4): 455-67. doi:10.1016/S0001-4575(97)00105-X, PMID: 9666242.

21) Stutts J, Feaganes J, Reinfurt D, Rodgman E, Hamlett C, Gish K, et al. Driver's exposure to distractions in their natural driving environment. Accid Anal Prev. 2005; 37 (6): 1093-101. doi: 10.1016/j.aap.2005.06.007, PMID:16011827.

22) Young KL, Lenné MG. Driver engagement in distracting activities and the strategies used to minimise risk. Saf Sci. 2010; 48 (3): 326-32. doi: 10.1016/j.ssci.2009.10.008.

23) Strayer DL, Drews FA, Crouch DJ. A comparison of the cell phone driver and the drunk driver. Human factors: Hum Factors. 2006; 48 (2): 381-91. doi: 10.1518/001872006777724471, PMID: 16884056. 